\title{
Research on Logistics Competitiveness of Yangtze River Delta Ports from the Perspective of Niche
}

\author{
Jie Gao, Xueping Li \\ College of Transport \& Communications, Shanghai Maritime University, Shanghai, China \\ Email: lixueping@stu.shmtu.edu.cn
}

How to cite this paper: Gao, J. and Li, X.P. (2019) Research on Logistics Competitiveness of Yangtze River Delta Ports from the Perspective of Niche. Journal of Transportation Technologies, 9, 309-324. https://doi.org/10.4236/jtts.2019.93019

Received: April 30, 2019

Accepted: May 27, 2019

Published: May 30, 2019

Copyright $\odot 2019$ by author(s) and Scientific Research Publishing Inc. This work is licensed under the Creative Commons Attribution International License (CC BY 4.0).

http://creativecommons.org/licenses/by/4.0/

\section{(c) (i) Open Access}

\begin{abstract}
The logistics industry is likened to be the "catalyst" of economic growth. It is one of China's top ten key revitalization and adjustment industries, and port logistics is the main force to promote regional logistics and regional economic development. This paper, which is based on the niche theory and its corresponding measurement method, establishes the niche evaluation indicator dimension of the development competitiveness of port logistics in the Yangtze river delta. In this paper, the niche width model, niche overlap model, niche suitability and evolutionary momentum model were used to conduct an empirical study on the development competitiveness of nine typical ports in the Yangtze river delta region from 2013 to 2017. Finally, according to the expansion of ecological niche, the separation of ecological niche and the symbiosis of ecological niche, the paper put forward the suggestions for the sustainable development of port logistics in the Yangtze river delta region.
\end{abstract}

\section{Keywords}

Port Logistics, Niche, Competitiveness, Yangtze River Delta Ports

\section{Introduction}

At present, economic globalization, trade liberalization and transportation integration have enabled the rapid development of port logistics. Recently, the publication and issuance of the three-year action plan for the integrated development of the Yangtze river delta region (2018-2020) mark that the integration of the Yangtze river delta region has stepped up to a new level. With the gradual deepening of economic integration in the Yangtze river delta, the stakeholders need mutually beneficial cooperation and seek breakthroughs in cooperation. 
However, at present, the coordination degree of port logistics in the Yangtze river delta region is not high, and the regional differences are large. The development of port logistics in the whole Yangtze river delta region is not balanced, and the port logistics layout and the network infrastructure lack of coordination, which seriously restricts the development process of port logistics in the region and the realization of the strategic goal of docking the international logistics system.

Therefore, it is of great practical significance to study the competitiveness of port logistics for the healthy development of port logistics. The development level of port logistics is not only related to the regional economic development, but also affects the competitiveness of regional logistics. Therefore, it is particularly important to evaluate the logistics competitiveness of Yangtze river delta ports. It is directly related to the future development space of Yangtze river delta ports and the construction of a world-class urban agglomeration in the Yangtze river delta.

The concept of Niche originates from biology. Grinnell (1917) first proposed the concept of Niche, which is "the last distribution unit occupied by exactly one species or subspecies" [1]. Later, Hutchinson (1957), from the perspective of space and resource allocation, believed that the survival of organisms depended on a variety of factors, and organisms needed to survive and develop under the support of factors suitable for their survival, which together constituted the ecological niche of the organisms [2]. Whittaker (1975) believed that ecological niche is the specific status, behavior and relationship of species in their living environment. Niche overlap is an important content of niche theory. Niche overlap refers to the similarity of species in development, so they will compete [3]. With the consolidation of the theoretical basis of evolutionary ecology in species, population, industrial population and other fields, the quantifiable and measurable ecological niche began to be paid attention to. Dimmick (1993) proposed that the viability of the population in the face of competition could be determined by niche analysis, i.e. niche suitability, width, overlap and dominance [4]. Odling-Smee et al. (2013) pointed out that, due to the biological characteristics and other adaptive characteristics formed by environmental changes and niche construction, the driving force of co-evolution of organisms depends on the feedback effect of natural selection in the environment that can be changed by niche construction [5].

In China, Jin Hanxin et al. (2008) first introduced niche theory into the study of port development [6]. At present, the research on solving port clustering using the niche theory is mainly focused on qualitative analysis of port competition, cooperation strategy and evaluation of port logistics capability by niche theory.

In this paper, the port logistics industry in the Yangtze river delta region is regarded as a logistics ecosystem, and each port is regarded as the ecological element of the logistics ecosystem. On the basis of referring to previous studies, 
the competitiveness of port logistics is evaluated by using niche theory and relevant calculation model.

\section{Niche theory of Port Logistics}

\subsection{Niche Width}

The niche width of port logistics refers to the actual range or potential capacity of port logistics to adapt to the environment and utilize resources. In this paper, it can be understood as the degree of each port's occupation of the same logistics resources. For example, the number of berths, 10,000-ton berths, etc. The wider the niche, the greater the degree of logistics resources occupied by the port, the better the development environment, and the higher the efficiency of resource utilization. And vice versa.

Levins formula has been widely used in recent years because of its simple calculation and clear ecological significance. The calculation formula of niche width is as follows:

$$
A_{i}=-\sum_{j}^{M} P_{i j} \log P_{i j}
$$

In Formula (1), $A_{i}$ is the niche breadth of $i$ port logistics; $P_{i j}$ is the utilization rate of $i$-th port to logistics resource $j$, and $M$ is the total amount of logistics resources owned by the nine Yangtze river delta ports.

\subsection{Niche Differentiation Degree}

The niche diversity refers to the difference in niche breadth between ports, and reflects the separation between ports within the Yangtze River Delta as a whole. The higher the degree of differentiation, the more obvious the niche separation trend, and the less intense the competition; vice versa. Its calculation formula is as follows:

$$
B=\sqrt{\sum_{i=1}^{n}\left[\left(\frac{A_{i}}{\bar{A}}\right)-1\right]^{2} / n}
$$

In Formula (2): $A_{i}$ is the logistics niche width value of the $i$-th port; The denominator is the average logistics niche width of each port; $n$ is the number of ports.

\subsection{Niche Overlap}

Niche overlap refers to the phenomenon that two or more species with similar niches share or compete for common resources when living in the same space. Two species with overlapping ecological niches cannot coexist for a long time due to the principle of competitive exclusion, unless the space and resources are abundant, which are usually limited [7].

Based on the previous literature, this paper defines niche overlap as the degree of competition between ports in terms of their adaptation to the logistics devel- 
opment environment and their actual utilization or potential development ability of logistics resources. The calculation formula is as follows:

$$
C_{i j}=\frac{\sum_{k=1}^{l} P_{i k} P_{j k}}{\sqrt{\sum_{k=1}^{1}\left(P_{i k}\right)^{2} \sum_{k=1}^{1}\left(P_{j k}\right)^{2}}}
$$

Among them, $C_{i j}$ represents the niche overlap indicator between ports $i$ and $j$; $P_{i k}$ and $P_{j k}$ represent the values of the $i$ or $j$ port in the resource $k$ category $(k \in l)$.

\subsection{Niche's "Condition" and "Potential"}

Zhu chunquan (1997) believed that ecological niche was "the relative status and role of biological units formed in the process of interaction between biological units and the environment in a specific ecosystem" [8]. Ecological niche includes two aspects: one is the condition of the biological unit, namely its current situation (energy, biomass, resource occupancy, adaptability, etc.); The other is the potential of biological units to reflect their realistic influence or dominance over the environment, and to reflect the potential development trend. The synthesis of "condition" and "potential" reflects the relative status and role of specific biological units in the ecosystem [8]. After the data and weight are determined, the "state" and "potential" of the ecological niche are calculated as follows:

$$
D_{i}=\sum_{j}^{m}\left(P_{j} * \omega_{j}\right)
$$

Among them, $P_{j}$ is the value of the $j$-th class resource standardization (2017 data), $\omega_{j}$ is the weight of the $j$-th class indicator, and $\mathrm{m}$ is the number of indicators.

$$
E_{i}=\sum_{j}^{m}\left(Q_{j} * \omega_{j}\right)
$$

$Q_{j}$ is the average annual growth rate after standardization of category $j$ resources (2013-2017), $\omega_{j}$ is the weight of the $j$-thindicator, and $\mathrm{m}$ is the number of indicators.

\subsection{Niche Suitability and Evolutionary Momentum}

Niche suitability of port logistics refers to the degree of closeness between the realistic niche and the most suitable niche for the development of port logistics industry. Evolutionary momentum characterizes the intensity of the effect of realistic niche of port logistics on the trend of its optimal niche. The higher the niche suitability of the port is, the better the logistics development of the port will be. The larger the evolutionary momentum, the greater the gap between the actual ecological niche and the optimal ecological niche of the port, and the larger the improvement space of the port. In the niche suitability evaluation of logistics industry, a mathematical measurement model of niche suitability was built according to the evaluation indicator system: 


$$
F_{i}=\sum_{j=1}^{n} \omega_{j} \frac{\min \left\{\left|x_{i j}^{\prime}-x_{a j}\right|\right\}+\alpha \max \left\{\left|x_{i j}^{\prime}-x_{a j}\right|\right\}}{\left|x_{i j}^{\prime}-x_{a j}\right|+\alpha \max \left\{\left|x_{i j}^{\prime}-x_{a j}\right|\right\}}
$$

In the formula, $F_{i}$ represents the niche suitability value of the $i$-th port logistics, $\omega_{j}$ represents the weight of each ecological situation factor, $x_{i j}^{\prime}$ represents the realistic ecological niche of each port logistics, $X_{a j}$ is the optimal ecological niche of each port logistics, and $\alpha(0 \leq \alpha \leq 1)$ is the model parameter. Among them, the optimal ecological niche of life situation factor is:

$$
x_{\alpha j}=\max \left(x_{i j}^{\prime}\right), j=1,2, \cdots, n
$$

where $x_{\alpha j}$ represents the best niche of the $j$-th ecological potential factor and $x_{i j}^{\prime}$ represents the realistic niche of the $i$-th port group ecological potential factor $j$.

\subsubsection{Determine Model Parameter and Evolutionary Momentum}

$\alpha(0 \leq \alpha \leq 1)$ is the model parameter, and the calculation process is as follows [9]:

$$
\begin{gathered}
\alpha=\frac{\overline{\varphi_{i j}}-2 \varphi_{\min }}{\varphi_{\max }} \\
\varphi_{i j}=\left|x_{i j}^{\prime}-x_{a j}\right| \\
\overline{\varphi_{i j}}=\frac{1}{m n} \sum_{i=1}^{n} \sum_{j=1}^{m} \varphi_{i j}
\end{gathered}
$$

where, $\varphi_{i j}$ represents the difference between the actual logistics ecological niche of the port and the most appropriate logistics ecological niche, and $\overline{\varphi_{i j}}$ represents the mean value of these differences.

\subsubsection{Evolutionary Momentum}

Evolutionary momentum characterizes the intensity of the effect of realistic niche of port logistics on the trend of its optimal niche. The calculation formula is as follows:

$$
G_{i}=\sqrt{\frac{\sum_{j=1}^{m}\left|x_{i j}^{\prime}-x_{a j}\right|}{m}}
$$

$G_{i}$ represents the evolutionary momentum of port $i, m$ is the total amount of logistics resources owned by the each port. The larger the evolutionary momentum, the greater the gap between the actual ecological niche and the optimal ecological niche of the port, and the larger the improvement space of the port.

\section{Data Source and Indicator Selection}

\subsection{Data Source and Processing}

According to the ports with the highest cargo throughput and container throughput in China port yearbook 2018, and based on the availability of each indicator, nine major ports in the Yangtze river delta region were selected for 
analysis and research. The research data were obtained from statistical yearbooks of the Yangtze river delta (2014-2018), Shanghai statistical yearbook (2014-2018), Ningbo statistical yearbook (2014-2018) and other relevant statistical communiques.

Data should be standardized prior to analysis. In this paper, multiple indicators are involved in different orders of magnitude. First, the data are standardized. Considering the principle of invariance of the relative difference of the internal data of the same indicator and the principle of constancy of the total quantity, this paper adopts the specific gravity method to eliminate the standardized value affected by dimension and order of magnitude [10].

\subsection{Indicator Selection and Weight Determination}

This paper follows the principles of science, system, and availability in the selection of indicators. Based on the research at home and abroad, the Yangtze River Delta Port Logistics is constructed from the three dimensions of resource dimension niche, economic dimension niche, and technology dimension niche. The evaluation dimension of competitiveness is to study the logistics competitiveness of nine ports in the 2013-2017 Yangtze River Delta region.

Determining the weight of the indicator can reflect the relative importance and status of the indicator in the system evaluation system. In this paper, the entropy method is used to calculate the weight of each evaluation indicator [11]. The entropy method is used to determine the attribute weight and reflect the dispersion degree of the attribute value by using the decision matrix, so as to reduce the influence of the extreme value on the comprehensive evaluation, and then comprehensively evaluate and analyze the advantages and disadvantages of the object. The results are shown in Table 1.

\section{Empirical Analysis of Logistics Niche Measurement of Yangtze River Delta Ports}

\subsection{Port Logistics Niche Breadth and Differentiation Measure}

\subsubsection{Niche Width}

The wider the niche, the more likely it is to be a generalized species. If the resources themselves are not sufficiently secure, then as a competitor, generalized species will prevail over specialized species. On the other hand, specialized species occupy very narrow ecological niches and have special adaptive ability to utilize certain resources. When resources can ensure supply and regeneration, the competitive ability of specialized species will exceed that of generalized species [12].

According to the status and function of the population in the community, it can be divided into four types, namely dominant species, subdominant species, Auxiliary species and rare species [13]. In this paper, the size of niche width value of logistics in Yangtze river delta ports from 2013 to 2017 was calculated, and K-means clustering analysis was conducted using SPSS.20. The results are shown in Table 2. 
Table 1. Evaluation indicators and weights.

\begin{tabular}{|c|c|c|c|c|c|}
\hline Level indicators & Weights & Secondary indicators & Weights & Three-level indicator & Weights \\
\hline \multirow{5}{*}{$\begin{array}{l}\text { Resource } \\
\text { dimension }\end{array}$} & \multirow{5}{*}{0.3610} & \multirow{3}{*}{ infrastructure } & \multirow{3}{*}{0.3743} & Berth length & 0.2661 \\
\hline & & & & Number of port berths (for production) & 0.2782 \\
\hline & & & & Number of 10,000-ton berths (for production) & 0.4557 \\
\hline & & \multirow[b]{2}{*}{ Logistics scale } & \multirow[b]{2}{*}{0.6257} & Cargo throughput (100 million tons) & 0.2344 \\
\hline & & & & Container throughput $(10,000 \mathrm{TEU})$ & 0.7656 \\
\hline \multirow{8}{*}{$\begin{array}{l}\text { Economic } \\
\text { dimension }\end{array}$} & \multirow{8}{*}{0.2294} & \multirow{8}{*}{$\begin{array}{c}\text { Hinterland } \\
\text { economic level }\end{array}$} & \multirow{8}{*}{1} & Per capita GDP (yuan) & 0.0271 \\
\hline & & & & Per capita tertiary industry (yuan) & 0.0797 \\
\hline & & & & Per capita import/export $(\$)$ & 0.4280 \\
\hline & & & & Proportion of tertiary industry in GDP & 0.0096 \\
\hline & & & & Per capita retail sales of social consumer goods (yuan) & 0.1157 \\
\hline & & & & Per capita disposable income (yuan) & 0.0305 \\
\hline & & & & Per capita consumption expenditure (yuan) & 0.0447 \\
\hline & & & & Resident population at the end of the year ( 10,000 people $)$ & 0.2646 \\
\hline \multirow{7}{*}{$\begin{array}{l}\text { Technical } \\
\text { dimension }\end{array}$} & \multirow{7}{*}{0.4095} & \multirow{7}{*}{$\begin{array}{c}\text { Development } \\
\text { potential }\end{array}$} & \multirow{7}{*}{1} & GDP growth rate & 0.0063 \\
\hline & & & & Cargo throughput growth rate & 0.0961 \\
\hline & & & & Container throughput growth rate & 0.2581 \\
\hline & & & & Import and export volume growth rate & 0.1329 \\
\hline & & & & Growth rate of retail sales of consumer goods & 0.0216 \\
\hline & & & & Practitioner (10,000 people) & 0.4241 \\
\hline & & & & Employment growth rate & 0.0610 \\
\hline
\end{tabular}

Table 2. Port types and niche breadth in the Yangtze River Delta.

\begin{tabular}{cccccc}
\hline & Ecotype & $\begin{array}{c}\text { Resource dimension } \\
\text { niche width }\end{array}$ & $\begin{array}{c}\text { Economic dimension } \\
\text { niche width }\end{array}$ & $\begin{array}{c}\text { Technology } \\
\text { dimension niche width }\end{array}$ & $\begin{array}{c}\text { Total niche } \\
\text { width }\end{array}$ \\
\hline Ningbo-Zhoushan port & Dominant species & 1.7083 & 2.1190 & 1.0869 & 4.9142 \\
Shanghai port & Dominant species & 1.6737 & 2.2929 & 0.5846 & 0.8635 \\
Suzhou port & Subdominant species & 1.1738 & 2.2939 & 0.8184 & 3.3312 \\
Nanjing port & Subdominant species & 0.9128 & 2.0424 & 1.1467 & 3.7735 \\
Huzhou port & Auxiliary species & 0.7293 & 1.6099 & 0.9894 & 3.3354 \\
Nantong port & Auxiliary species & 0.6352 & 1.7108 & 1.0539 & 3.2999 \\
Taizhou port & Auxiliary species & 0.6952 & 1.5508 & 0.6701 & 3.1088 \\
Zhenjiang port & Auxiliary species & 0.7856 & 1.6531 & 0.5056 \\
Lianyungang port & Rare species & 0.7830 & 1.2354 & & 2.5239 \\
\hline
\end{tabular}


As can be seen from Table 2, the total niche width of logistics of dominant species (Shanghai port, Ningbo-Zhoushan port) is the widest, and its competitiveness in logistics resources is far greater than that of other ports. It indicates that the two ports are able to adapt to the living environment of the region well, and the niche widths of the two ports are relatively close, so there is great competitive pressure between them.

The sub-dominant species (Suzhou Port, Nanjing Port) have a slightly lower total logistics niche than the dominant species, but the difference in niche width between the two ports is relatively large, indicating that the competitiveness between the two ports is relatively low.

The logistics competitiveness of the auxiliary species (huzhou port, nantong port, taizhou port and zhenjiang port) is relatively weak. Rare species (lianyungang) have the smallest niche width, port logistics development occupies less resources than other ports, and is at a disadvantage in survival and development. It is mainly caused by the fact that the port is furthest away from the Yangtze river and the lack of resources investment, economy and technological innovation.

The calculation results of the total niche width were input into ArcGIS10 software, Jenks optimal breaking point method [14] was used for cluster visualization, and finally the niche width type map of Yangtze river delta port was formed, as shown in Figure 1.

It can be seen from Figure 1 that the distribution of logistics resources in the Yangtze River Delta is uneven, gradually decreasing from east to west. Most of

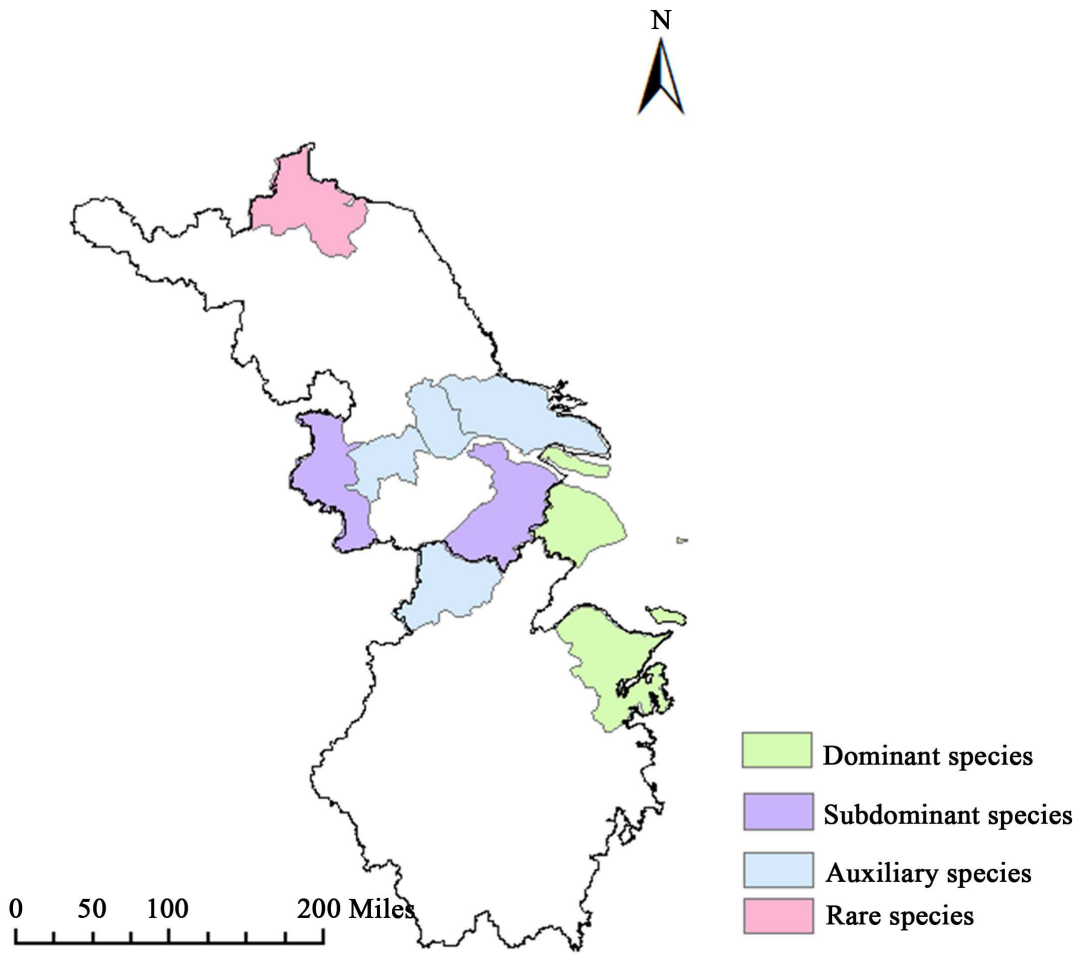

Figure 1. Map of the ecological element types in the Yangtze River Delta. 
the logistics resources are mainly concentrated in Shanghai Port and Ningbo-Zhoushan Port. The inland ports are relatively weak in terms of resources, economy and technology, especially Lianyungang port, which is away from the Yangtze River Basin.

On the one hand, the reasons for this phenomenon are related to regional location and government policy preferences. Moreover, the cities have different emphasis on port logistics development. Due to their special policy advantages, Shanghai port and Ningbo-Zhoushan Port are better in terms of logistics personnel, technology and infrastructure than other ports, with a higher level of logistics development, which means that the logistics resources are sufficient and the logistics competitiveness is also high. On the other hand, the economic development level of the hinterland plays a role. The higher the economic development level is, the more supportive the logistics development will be. The economic development will provide guarantee for the infrastructure and development funds of the logistics industry, and at the same time, it can attract more logistics talents and resources.

\subsubsection{Niche Differentiation}

The differentiation degree of logistics niche in Yangtze river delta ports is shown in Figure 2. From 2013 to 2014, it showed a slow rising trend. This indicates that the difference in logistics development among the ports in the Yangtze river delta expanded from 2013 to 2014 . The reason for this phenomenon may be that the niche expansion of Shanghai port and zhenjiang port was slightly higher than the contraction of nantong port and huzhou port, thus increasing the overall internal difference.

At the same time, the generalization of niche widths of Shanghai port and Zhenjiang port and the specialization of niche widths of Nantong port and Huzhou port increase the degree of niche separation of the whole port industry. However, after 2014, the differentiation degree among ports in the Yangtze river delta is relatively high and gradually tends to be stable, indicating that the trend of logistics niche separation among ports is becoming more and more obvious, while the degree of competition is becoming less and less intense.



Figure 2. 2013-2017 Yangtze River delta port logistics niche width and differentiation. 


\subsection{Niche Overlap Measure}

Niche overlapping theory holds that competition not only depends on the occupation of factor resources, but also depends on the niche width and the degree of resource differentiation among competing subjects. Fierce competition only occurs when niche width is small and differentiation degree of factor resources is not obvious. In the case of wide niche width, they can coexist even if the differentiation of factor resources is not obvious and there is some overlap between ecological elements. According to Formula (3), the results are shown in Table 3.

As can be seen from Table 3, as the dominant species, Ningbo-Zhoushan port and Shanghai port have a high overlapping value with other ports, such as shanghai-Nanjing port and Ningbo-Zhoushan port and Nanjing port, respectively reaching 0.7370 and 0.8071 (The closer the value get to 1 , the higher the resource overlap between the two ports will be, and the higher the competitiveness will be.). However, due to the large niche width of dominant species (Ningbo-Zhoushan port, Shanghai port) and subdominant species (Nanjing port), the actual competition between the two ports for Nanjing port is not so fierce; As a subdominant species, Suzhou port and Nanjing port have a high degree of overlap with each other, and both have a high degree of overlap with the neighboring ports in Jiangsu province. For example, the overlap degree between Nanjing port and Zhenjiang port reaches 0.8972 , and the niche width of Zhenjiang port is much lower than that of Nanjing port, indicating that Nanjing port has strong competitive pressure on Zhenjiang port. The overlapping degree of the auxiliary species with the dominant species ports of Nantong port, Taizhou port, Zhenjiang port and Huzhou port is mostly at a low level, which also shows that they are auxiliary with the dominant species. As a rare species, Lianyungang has a large degree of overlap with other ports (except Huzhou port), and the niche width of Lianyungang is the lowest, showing a relatively obvious niche overlap, indicating that Lianyungang has a relatively fierce competition with other ports.

Table 3. Overlapping degree of logistics niche in the Yangtze River Delta.

\begin{tabular}{|c|c|c|c|c|c|c|c|c|c|}
\hline & SH port & LYG port & NT Port & TZ Port & ZJ Port & SZ Port & NJ Port & HZ Port & NB-ZS port \\
\hline Shanghai port & 1.0000 & 0.6760 & 0.5398 & 0.4659 & 0.5515 & 0.6192 & 0.7370 & 0.4448 & 0.7865 \\
\hline Lianyungang port & & 1.0000 & 0.8494 & 0.7707 & 0.7795 & 0.6733 & 0.8844 & 0.5599 & 0.7796 \\
\hline Nantong Port & & & 1.0000 & 0.9193 & 0.7281 & 0.6168 & 0.8428 & 0.7949 & 0.6585 \\
\hline Taizhou Port & & & & 1.0000 & 0.7303 & 0.5464 & 0.7655 & 0.8607 & 0.6225 \\
\hline Zhenjiang Port & & & & & 1.0000 & 0.7258 & 0.8972 & 0.7347 & 0.7588 \\
\hline Suzhou Port & & & & & & 1.0000 & 0.7988 & 0.4737 & 0.7876 \\
\hline Nanjing Port & & & & & & & 1.0000 & 0.6495 & 0.8071 \\
\hline Huzhou Port & & & & & & & & 1.0000 & 0.5866 \\
\hline Ningbo-Zhoushan port & & & & & & & & & 1.0000 \\
\hline
\end{tabular}


Through the above analysis, it can be found that the ports with similar total niche of logistics niche have higher niche overlap values; in general, the logistics competition pressure between ports in the Yangtze River Delta region is relatively large, mainly for the inland rivers. Hong Kong is very competitive. The hinterland cities where ports and ports are located need to effectively integrate and utilize their own logistics resources, formulate reasonable logistics development plans, and increase their niche breadth, thus reducing the niche overlap with other ports and competing with each other. pressure.

\subsection{Ecological Niche "Condition" and "Potential"}

According to the calculation results of "condition" and "potential", the scatter diagram illustrated by Figure 3 can be drawn. The X-axis represents the "condition" of port ecological niche, and the Y-axis represents the "potential" of port ecological niche. The diagram is centered on $(0.65,0.25)$ in order to spread all the ports over four regions to analyze the difference between "condition" and "potential" of the ports ecological niches.

1) In the first quadrant, the "condition" and "potential" of ecological niche are very high. These ports have a good industrial foundation and a strong development trend, and their comprehensive competitiveness is very strong. However, the nine major Yangtze river delta ports studied in this paper are not in the first quadrant.

2) In the second quadrant-Huzhou port, Taizhou port and Nantong port. They are in the lowest state of their ecological niche, but in the highest quadrant of their potential. The former indicates that the port has a large market opportunity and a good prospect, while the latter indicates that these ports have problems in the development and utilization of resources. Although it does not have a strong economic and resource base, it has a strong growth trend and may become a sunrise industry.

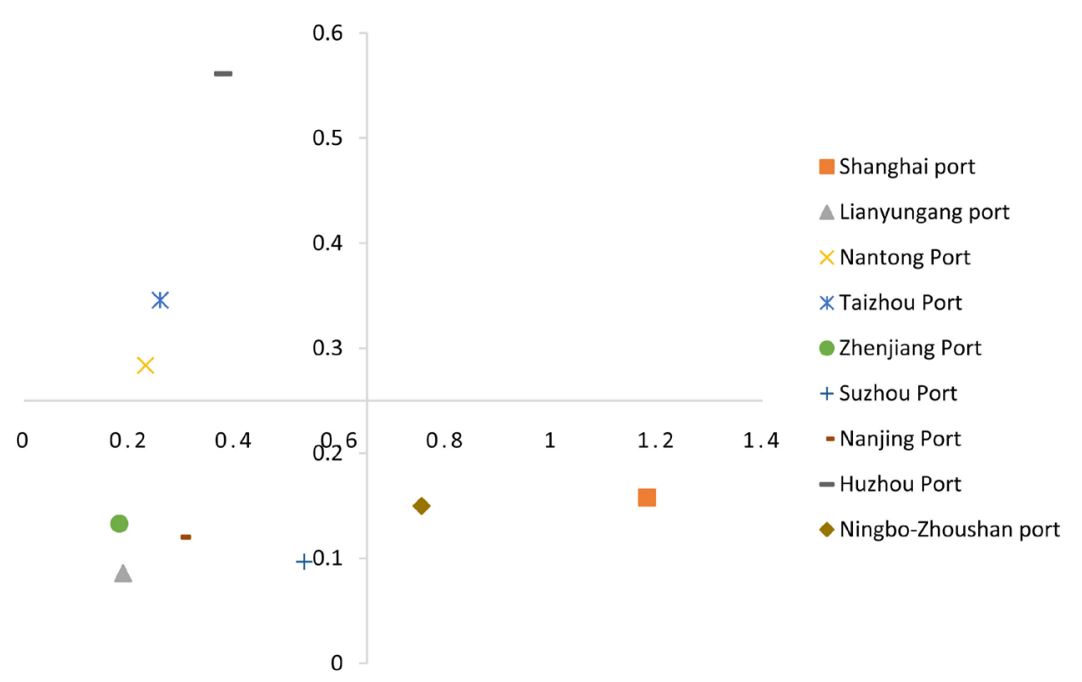

Figure 3. Condition and potential of logistics ecological niche in the Yangtze river delta ports. 
3) In the third quadrant-Zhenjiang port, Lianyungang port and Nanjing port. The "condition" and "potential" of the ecological niche are at the lowest level, indicating that these ports have neither a good industrial base nor a declining trend. Businesses with extremely low market share should be eliminated immediately and their dedicated resources should be transferred to other port operations. Finally, integrate port resources and actively cooperate with other ports.

4) In quadrant 4-Shanghai port, Ningbo-Zhoushan port. It has the highest "condition", but its "potential" is low, indicating that these two ports have sufficient logistics resources and capital base, especially Shanghai port. However, the current development trend is not good and bottlenecks in the development may exist. However, port enterprises do not have to invest a lot to expand the market scale. At the same time, as the market leader, the port enjoys the advantages of scale economy and high marginal profit. Therefore, strengthening the cooperation and coordination of Yangtze river delta ports will bring a lot of financial resources to the port enterprises in the future.

\subsection{Niche Suitability and Evolutionary Momentum}

It can be seen from Table 4 that the dominant portability of the dominant species ports (Shanghai Port, Ningbo-Zhoushan Port) ranks in the top 2, indicating that both port logistics developments are in the leading position in the Yangtze River Delta region, and the evolutionary momentum values are very low. At

Table 4. Suitability, comprehensive suitability and evolutionary momentum of each dimension of the Yangtze River Delta.

\begin{tabular}{|c|c|c|c|c|c|}
\hline & $\begin{array}{c}\text { Resource } \\
\text { dimension }\end{array}$ & $\begin{array}{l}\text { Economic } \\
\text { dimension }\end{array}$ & $\begin{array}{l}\text { Technical } \\
\text { dimension }\end{array}$ & $\begin{array}{l}\text { Comprehensive } \\
\text { suitability }\end{array}$ & $\begin{array}{c}\text { Evolutionary } \\
\text { momentum }\end{array}$ \\
\hline Shanghai port & $\begin{array}{c}0.8619 \\
(1)\end{array}$ & $\begin{array}{c}0.4896 \\
(2)\end{array}$ & $\begin{array}{c}0.6169 \\
(1)\end{array}$ & $\begin{array}{c}0.8920 \\
(1)\end{array}$ & $\begin{array}{c}0.2824 \\
(9)\end{array}$ \\
\hline Lianyungang port & $\begin{array}{c}0.2046 \\
(6)\end{array}$ & $\begin{array}{c}0.2193 \\
(8)\end{array}$ & $\begin{array}{c}0.2237 \\
(6)\end{array}$ & $\begin{array}{c}0.2719 \\
(8)\end{array}$ & $\begin{array}{c}0.4707 \\
(2)\end{array}$ \\
\hline Nantong Port & $\begin{array}{c}0.1586 \\
(9)\end{array}$ & $\begin{array}{c}0.1586 \\
(9)\end{array}$ & $\begin{array}{c}0.1586 \\
(9)\end{array}$ & $\begin{array}{c}0.1979 \\
(9)\end{array}$ & $\begin{array}{c}0.6080 \\
(1)\end{array}$ \\
\hline Taizhou Port & $\begin{array}{c}0.1962 \\
(8)\end{array}$ & $\begin{array}{c}0.2364 \\
(7)\end{array}$ & $\begin{array}{c}0.3894 \\
(3)\end{array}$ & $\begin{array}{c}0.3408 \\
(5)\end{array}$ & $\begin{array}{l}0.4281 \\
(5)\end{array}$ \\
\hline Zhenjiang Port & $\begin{array}{c}0.2023 \\
(7)\end{array}$ & $\begin{array}{c}0.2463 \\
(6)\end{array}$ & $\begin{array}{c}0.2144 \\
(8)\end{array}$ & $\begin{array}{c}0.2774 \\
(7)\end{array}$ & $\begin{array}{c}0.4617 \\
(3)\end{array}$ \\
\hline Suzhou Port & $\begin{array}{c}0.2660 \\
(4)\end{array}$ & $\begin{array}{c}0.7216 \\
(1)\end{array}$ & $\begin{array}{c}0.2219 \\
(7)\end{array}$ & $\begin{array}{c}0.4263 \\
(4)\end{array}$ & $\begin{array}{c}0.3981 \\
(6)\end{array}$ \\
\hline Nanjing Port & $\begin{array}{c}0.2076 \\
(5)\end{array}$ & $\begin{array}{c}0.2950 \\
(4)\end{array}$ & $\begin{array}{c}0.2370 \\
(5)\end{array}$ & $\begin{array}{c}0.2979 \\
(6)\end{array}$ & $\begin{array}{c}0.4308 \\
(4)\end{array}$ \\
\hline Huzhou Port & $\begin{array}{c}0.2687 \\
(3)\end{array}$ & $\begin{array}{c}0.2875 \\
(5)\end{array}$ & $\begin{array}{c}0.5516 \\
(2)\end{array}$ & $\begin{array}{c}0.4933 \\
(3)\end{array}$ & $\begin{array}{c}0.3925 \\
(7)\end{array}$ \\
\hline Ningbo-Zhoushan port & $\begin{array}{c}0.5416 \\
(2)\end{array}$ & $\begin{array}{c}0.3830 \\
(3)\end{array}$ & $\begin{array}{c}0.2476 \\
(4)\end{array}$ & $\begin{array}{c}0.5401 \\
(2)\end{array}$ & $\begin{array}{c}0.3612 \\
(8)\end{array}$ \\
\hline
\end{tabular}


present, there is no need to invest too much (which means that the current investment situation should be maintained, and there is no need to increase investment) just strengthen cooperation with surrounding ports and focus on its own business. The suitability of each dimension of other ports is lower than that of the dominant species ports, which are relatively balanced, indicating that these port logistics development prospects are relatively large, and the integration and rational utilization of port resources should be strengthened.

The economic dimension of Suzhou port is the most suitable, but the corresponding resource and technology dimension is not. This shows that the hinterland of Suzhou port has a good economic development, but the logistics scale, infrastructure and technological innovation are not strong enough. However, the Nantong port has the lowest figures for all the dimensions. As a sub-dominant species, its port ecological niche is relatively wide, which may be caused by the fact that Nantong port has not given full play to its resource advantage.

From the result of ranking of comprehensive ecological suitability degree, Shanghai port takes the first place, which indicates that it plays a dominant role in the whole port logistics and plays a key role in the dominant population; Nantong port is at the bottom of the list as it has a relatively low position in the logistics field of ports in the Yangtze river delta. The port is quite deficient in the development of resources, economy and technology and fails to make full use of its own resources; The comprehensive ecological suitability of the remaining ports is close to the ecological suitability of each dimension. The logistics niche of most of the auxiliary species and the rare port is relatively low, indicating that the allocation and positioning of resources, economy and technology are not optimal, resulting in weaker logistics services and leading functions for other ports. Low, and thus become an important bottleneck to inhibit the development of port logistics in the Yangtze River Delta region. In general, the dominant ports haven't played a leading role in the whole Yangtze river delta port logistics.

From the results of evolutionary momentum, the ports ranking higher than the suitability are Lianyungang, Nantong, Zhenjiang and Nanjing ports, indicating that they can achieve a higher suitability level through resource integration. In order to better expand the port logistics ecological niche at the bottom of the list and improve the development level of port logistics, it is necessary for ports with higher ecological niche to play its pulling and radiating role, this requires cooperation from the ports' hinterland governments and introduce relevant policies to support it. so as to establish a good ecosystem of Yangtze river delta port logistics cluster and thus promote the sustainable development of Yangtze river delta port logistics.

\section{Conclusions}

This paper uses the concepts of niche breadth, niche overlap, niche suitability and evolutionary momentum to empirically analyze the logistics competitiveness of nine ports in the Yangtze River Delta region. The following conclusions are drawn: 
1) The port logistics niche of the Yangtze River Delta is centered on Shanghai Port and Ningbo-Zhoushan Port, and gradually decreases toward the two branches of Suzhou Port and Nantong Port. The dominant species (Shanghai Port, Ningbo-Zhoushan Port) has the highest logistics niche breadth and the strongest possession of logistics resources. Rare (Lianyungang) has the lowest logistics niche breadth and the logistics development environment needs to be improved. Since 2014, the separation trend of logistics niche between the nine ports in the Yangtze River Delta region has become more and more obvious, and the intensity of competition is getting lower and lower.

2) At present, the logistics competition among ports in the Yangtze river delta region still exists, mainly because the dominant ports (Shanghai port, Ningbo-Zhoushan port) still have strong competitiveness in logistics resources and economy for other ports.

3) The dominant species played a leading role in the Yangtze River Delta port, but did not fully play a leading role. The evolutionary momentum of the auxiliary species port and the rare port is ranked high, and the comprehensive niche suitability ranks backward, and there is still much room for improvement.

\section{Suggestions}

Further development strategies to improve port logistics in the Yangtze river delta region using niche expansion, niche separation and niche symbiosis can be imagined:

\subsection{Niche Expansion Strategy}

The niche expansion of port logistics includes two aspects. The first is to expand the scope of port logistics resources; the second is to improve the efficiency of logistics resources to prevent the waste of logistics resources. The logistics development level of Shanghai port and Ningbo-Zhoushan port is relatively high, with strong possession of logistics resources and very good infrastructures compared with other regions. However, in the later stage, new infrastructures should be conceived to enhance the ecological niche of the logistic development dimension. The niche width of Nanjing port is very large, but the current development situation is in a low state. Therefore, the rational use of their existing port logistics resources should be encouraged. For ports with weak logistics development, such as Lianyungang and Zhenjiang port, etc. They should strengthen the construction of their own infrastructure and learn from the experience of logistics development of dominant ports and sub-dominant ports, so as to form a pattern that takes Shanghai port, and Ningbo-Zhoushan port as the center to drive the development of the surrounding ports. Finally, improve the utilization efficiency of logistics resources.

\subsection{Niche Separation Strategy}

The strategy of niche separation should be adopted for auxiliary and rare species 
ports. Firstly, they should integrate and optimize their own logistics resources and improve their comprehensive ecological niche. At the same time, for ports with a high ecological niche overlap value, such as dominant ports (Shanghai, Ningbo and Zhoushan), mutual cooperation should be strengthened to realize the linkage development model of coastal and inland logistics. This would realize the ecological niche separation.

\subsection{Niche Symbiosis Strategy}

The niche symbiosis strategy of port logistics ecosystem is strongly related to the strengthening of regional cooperation and development. Regional cooperation in port logistics can not only reduce logistics cost, but also improve logistics efficiency. To realize the regional cooperation of port logistics, it needs the planning and the support of national policies. All port hinterland cities should communicate and cooperate effectively according to the planning, and implement the mutual circulation of logistics talents and technologies by establishing an effective logistics resource exchange platform. All the ports should also strengthen the cooperation with the ports of other provinces and cities around them, in order to create cooperation area centered on the above seaports and the port of Ningbo-Zhoushan. This area will radiate to inland river ports to initiate the common development of port logistics in the Yangtze river delta.

\section{Conflicts of Interest}

The authors declare no conflicts of interest regarding the publication of this paper.

\section{References}

[1] Grinnell, J. (1917) The Niche-Relationship of the California Thrasher. Auk, 34, 427-433. https://doi.org/10.2307/4072271

[2] Hutchinson, G.E. (1957) Concluding Remarks: Cold Spring Harbor Symposium. Quantitative Biology, 22, 415-427. https://doi.org/10.1101/SQB.1957.022.01.039

[3] Whittaker, R.H. (1975) Communities and Ecosystems. Macmillan Publishing Company, New York.

[4] Dimmick, J. (1993) Ecology, Economics and Gratification Utilities. In: Alexander, A., Owers, J. and Carveth, R., Eds., Media Economics: Theory and Practice, Lawrence Erlbaum Associates, Hillsdale.

[5] Odling-Smee, F.J., Laland, K.N. and Feldman, M.W. (2013) Niche Construction: The Neglected Process in Evolution. Princeton University Press, Princeton. https://doi.org/10.1515/9781400847266

[6] Jin, H.X. and Huo, W. (2008) Research on the Niche Theory of Port Development. Journal of Nanjing University of Finance and Economics, No. 2, 48-50.

[7] Li, D.Z., Shi, Q., Yan, R.G., et al. (2006) Measurement Model of Species or Population Niche Breadth and Niche Overlap Degree. Forestry Science, No. 7, 95-103.

[8] Zhu, C.Q. (1997) Niche Situation Theory and Expansion Hypothesis. Journal of Ecology, 17, 324-332.

[9] Li, Z.Z. and Han, X.Z. (2006) A Population Evolutionary Dynamics Model with 
Ecological Position Construction and Its Application. Applied Mathematics and Mechanics, 27, 293-299. https://doi.org/10.1007/s10483-006-0307-1

[10] Liu, J.Y., Zhang, K. and Wang, G.H. (2008) Comparative Study on Data Standardization Methods in Comprehensive Evaluation. Digital Technology and Application, 36, 1-2.

[11] Li, J. and Liu, C. (2008) Research on Port Logistics Synergy in Beijing-Tianjin-Hebei Region from a Green Perspective. Value Engineering, 33, 6-7.

[12] Niu, C.J., Yan, A.R., Sun, R.Y., et al. (2015) Basic Ecology. Higher Education Press, Beijing, 149-151.

[13] Yuan, Q.M., Qin, C.C., Yang, R., et al. (2015) Analysis of Competition Strategy of Marine Industry in Coastal Provinces and Cities Based on Niche Theory. Marine Environmental Science, 34, 126-130.

[14] Ma, Y. and Tong, Y. (2018) Evaluation of Tourism Development Pattern and Spatial System Construction of Urban Agglomerations in the Middle Reaches of the Yangtze River Based on Ecological Niche Theory. Resources and Environment in the Yangtze River Basin, 27, 2-7. 